\title{
Association of the $B$ Blood Group Alleles with Production Characters in Chickens
}

\author{
Ikuo Okada, Tamotsu Hasegawa ${ }^{+, *}$, Shohachi Sekidera ${ }^{+* *}$ \\ Hiroshi SHImizu and Yoshio HachinoHe \\ (Department of Animal Science, Faculty of Agriculture, Hokkaido University, \\ Sapporo and +Omiya Livestock Breeding Station, Omiya)
}

(Received for Publication on March 25, 1966)

In recent years, many investigations have been performed with the aim of finding associations between quantitative polygenic characters and particular marker genes, such as those governing plumage color ${ }^{24)}$, comb types ${ }^{101}$ and transferrins ${ }^{4,13)}$. Concerning the blood groups of domestic animals, many studies of this sort have also been carried out by investigators interested in both theoretical and practical breeding problems.

In chickens, it has been shown that certain blood group polymorphisms are maintained by the selective advantage of heterozygotes. BRILzs et al. ${ }^{\text {7) }}$ and GILMour ${ }^{12)}$ found that segregation of genes at blood group loci, especially the $B$ locus, occurred in highly inbred populations. Direct evidence of heterozygote superiority at the $A$ and/or $B$ loci was given by ShuLTZ and BRILES ${ }^{23)}$ and OKADA and MATSUMOTO ${ }^{18}$. They reported that the observed frequencies of heterozygotes were higher than the expected frequencies in unselected populations, and that artificial selection for egg production further increased the proportion of heterozygotes.

These findings stimulated studies on possible relationships between blood group genes and production characters. As early as 1953, BRILES et al. ${ }^{8)}$ reported the effect of genotypes at the $B$ locus on body weight at 9 weeks of age. BriLes and ALLEN ${ }^{6)}$ found that the $B$ genotypes influenced viability and egg production. Evidence of the selective advantage of particular $B$-locus alleles was presented by ALLEN and GrLmour ${ }^{8)}$, based on a partial estimate of overall fitness, the arithmetic mean of juvenile and adult mortalities and egg production. The selection coefficient against $B^{21} / B^{13}$, when it was contrasted with $B^{21} / B^{14}$, was the order of 0.2. The immediate effect of the $B$-locus alleles was also analyzed by $\mathrm{ALLEN}^{21}$. Presence or absence of the alleles $B^{8}$ and $B^{9}$ was a significant source of variation in fertility and adult survival. Recently, Morron et al. ${ }^{16)}$ found that the $B$ blood group genotypes of zygotes, but not of dams, were associated with marked differences in mortality during incubation.

The purpose of this paper is to present some findings on association between the $B$-locus alleles and production characters in chickens, and to consider some oftheir practical implications.

\section{Materials and Methods}

Two strains, B and C, and their strain-cross progeny, all kept at the Omiya Livestock

* Present address : Okazaki Livestock Breeding Station, Okazaki, Aichi-ken.

** Present address: Shiraka wa Livestock Breeding Station, Shirakawashi, Fukushima-ken. 
Breeding Station, were used in these studies. Both strains are Single Comb White Leghorns, derived in 1952 from a single population which had been maintained by mass selection for egg production as a closed flock since 1938. Since 1952, both the B and $\mathrm{C}$ strains have been selected for their combining ability for egg production by reciprocal recurrent selection. Annual size of breeding population of each line was 50 to 100 females. The primary criterion in the performance test of strain-cross progeny was the rate of egg production during the first three laying months. Other economic characters such as sexual maturity, egg weight and hatchability were considered to some extent. About five female progeny per family were used for the performance test.

Data used in the present studies were obtained from 347 chickens of the B and $\mathrm{C}$ strains hatched in 1959 and 1961, and from 588 birds of the strain-cross hatched in 1962. Five measurements were taken on each bird. These are: sexual maturity, body weight, the rate and intensity of egg production, and egg weight. Sexual maturity was measured as the age in days when the first egg was laid. Measurements of body weight were taken in kilograms at the date of first egg. The rate of egg production was measured in percentage for the first three laying months. The intensity of egg production was calculated by the following formula:

$$
\text { Intensity of egg production }=\frac{\text { Number of eggs laid }}{\begin{array}{c}
\text { Number of days tested }(=90)-\text { Number } \\
\text { of days of winter pause }
\end{array}} \times 100
$$

Winter pause is defined as a period of non-production of seven or more consecutive days. Both the rate and intensity of egg production were transformed to the $\arcsin \sqrt{\text { percentage }}$ for variance analyses. The data on egg weight were obtained at the age of ten months and were available only for the $B$ and $C$ strains. Ten eggs per bird were weighed.

The serological methods and the nomenclature used in the present studies had been previously presented by Maтsumoto and OKADA ${ }^{14 /}$ and OKADA et al. ${ }^{101}$ Reagents were prepared at the Animal Science Laboratory of Hokkaido University, Sapporo, by isoimmunization within the University flock, which originated from crosses of the $\mathrm{B}$ and $\mathrm{C}$ strains of Omiya. All serological tests were carried out at Sapporo.

Blood samples were collected into test tubes from a wing vein and immediately sent from Omiya to the laboratory by air transportation. Usually the samples were en route only several hours and were received in good condition. After arrival, the blood samples were kept in a refrigerator $\left(3\right.$ to $\left.5^{\circ} \mathrm{C}\right)$, and all tests were carried out within one week after the blood had been drawn.

The method of statistical analysis for detecting pleiotropic effects of blood group genes is

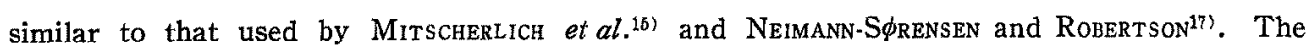
performance of chickens with a given blood group allele was compared with the performance of those lacking the gene. In order to eliminate the influence of genetic differences between sires all comparisons were made within sire families. The difference in average performance between these two groups within a sire family, $d$, was weighted according to the number of each group. The weighting factor is given by

$$
\omega=\frac{n_{1} n_{2}}{n_{1}+n_{2}}
$$

where $n_{1}$ is the number of chickens possessing the allele in question and $n_{2}$.is the number of those lacking it. The difference averaged over all sire families, $D$, is best estimated by 


$$
\bar{D}=\frac{\sum \omega d}{\sum \omega} .
$$

For determining the standard error of $D$, the within subclass variance $\sigma_{\omega}^{2}$ was used;

$$
S E_{D}=\sqrt{\frac{\sigma_{\omega^{2}}}{\sum \omega}} .
$$

In order to test joint effects of the genes at the $B$ locus, the $\chi^{2}$ test was used. As shown above, one can estimate the difference in performance, $D$, and its variance, $\sigma_{\omega}^{2} / \Sigma \omega$. If we divide the square of the estimate by its variance, we have a $\chi^{2}$ value with one degree of freedom. Then the sum of $n$ such independent variates is distributed as a $\chi^{2}$ distribution with $\mathrm{n}$ degrees of freedom, and this $\chi^{2}$ value is used to estimate the total variance controlled by blood group genes. If we designate $K_{f}$ as the proportion of the total variance within sire families which is controlled by the blood group alleles, and $N_{W}$ as the number of degrees of freedom within sires, then $K_{f}=\frac{\text { Excess } \chi^{2}}{N_{W}}$, where the excess $\chi^{2}$ is the observed $\chi^{2}$ value minus the number of degrees of freedom. Full details of this method were given by NermanNS $\phi$ RENSEN and ROBERTSON ${ }^{17}$.

For the detection of linkage between the $B$ locus and the genes influencing a given character, cocks heterozygous at the $B$ locus were used for mating. The progeny group of each sire was divided into two classes, namely those having the one allele and those with the other one. Analysis of variance was carried out to examine the difference between the segregation classes.

\section{Results}

In the studies six alleles at the $B$ locus were used for comparisons. They are $B^{A}, B^{B M}$, $B^{C}, B^{G}, B^{I}$ and $B^{M}$. As previously shown by OKaDA and Matsumoto ${ }^{18)}$, in the $B$ strain the

Table 1. Average effects of the $B$-locus alleles on sexual maturity.

\begin{tabular}{cccccc}
\hline Gene & Strain & $\begin{array}{c}\text { No. of sire } \\
\text { families }\end{array}$ & $\begin{array}{c}\text { No. of } \\
\text { hens }\end{array}$ & $\begin{array}{c}\text { Average effects } \\
\text { of genes }(D \pm S E \bar{D})\end{array}$ & $t$ \\
\hline$B^{4}$ & $\mathrm{C}$ B $\times$ B & 7 & 94 & $-1.44 \pm 5.06$ & 0.285 \\
& $\mathrm{~B}$ O $\times$ C 8 & 12 & 100 & $-2.34 \pm 2.95$ & 0.794 \\
$B^{E M}$ & $\mathrm{~B}$ & 14 & 143 & $-2.73 \pm 2.91$ & 0.939 \\
& $\mathrm{C} \times \mathrm{B}$ & 7 & 133 & $-0.11 \pm 2.70$ & 0.374 \\
& $\mathrm{~B} \times \mathrm{C}$ & 15 & 243 & $2.73 \pm 2.23$ & 0.042 \\
$B^{C}$ & $\mathrm{C}$ & 8 & 116 & $-0.88 \pm 3.46$ & 0.255 \\
& $\mathrm{C} \times \mathrm{B}$ & 11 & 207 & $-3.24 \pm 3.09$ & 1.047 \\
& $\mathrm{~B} \times \mathrm{C}$ & 9 & 152 & $2.62 \pm 2.62$ & 0.999 \\
$B^{G}$ & $\mathrm{C}$ & 7 & 89 & $-5.90 \pm 4.81$ & 1.227 \\
& $\mathrm{C} \times \mathrm{B}$ & 17 & 321 & $1.66 \pm 1.98$ & 0.838 \\
& $\mathrm{~B} \times \mathrm{C}$ & 13 & 175 & $-0.39 \pm 2.26$ & 0.172 \\
$B^{I}$ & $\mathrm{~B}$ & 15 & 147 & $-0.44 \pm 3.40$ & 0.130 \\
& $\mathrm{C}$ & 9 & 112 & $6.09 \pm 3.72$ & 1.638 \\
& $\mathrm{C} \times \mathrm{B}$ & 14 & 306 & $-2.57 \pm 1.94$ & 1.324 \\
& $\mathrm{~B} \times \mathrm{C}$ & 15 & 239 & $-1.87 \pm 2.22$ & 0.842 \\
$B^{M}$ & $\mathrm{~B}$ & 14 & 136 & $0.32 \pm 3.70$ & 0.086 \\
& $\mathrm{C} \times \mathrm{B}$ & 9 & 222 & $4.34 \pm 2.15$ & $2.023^{*}$ \\
& $\mathrm{~B} \times \mathrm{C}$ & 16 & 251 & $1.52 \pm 1.99$ & 0.764 \\
\hline
\end{tabular}

* Signi ficant at the $5 \%$ level of probability. 
Okada - Hasegawa - Sekidera $\cdot$ Shimizu $\cdot$ Hachinohe

Table 2. Average effects of the $B$-locus alleles on body weight at the date of first egg.

\begin{tabular}{|c|c|c|c|c|c|}
\hline Gene & Strain & $\begin{array}{l}\text { No. of sire } \\
\text { families }\end{array}$ & $\begin{array}{l}\text { No. of } \\
\text { hens }\end{array}$ & $\begin{array}{c}\text { Average effcts } \\
\text { of genes }(D \pm S E \bar{D})\end{array}$ & $t$ \\
\hline$B^{A}$ & 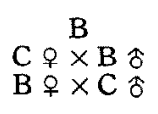 & $\begin{array}{r}7 \\
6 \\
12\end{array}$ & $\begin{array}{r}92 \\
102 \\
211\end{array}$ & $\begin{array}{l}-0.039 \pm 0.035 \\
-0.053 \pm 0.027 \\
-0.022 \pm 0.025\end{array}$ & $\begin{array}{l}1.117 \\
1.919 \\
0.886\end{array}$ \\
\hline$B^{B M}$ & $\begin{array}{l}\mathrm{B} \\
\mathrm{B} \times \mathrm{B}\end{array}$ & $\begin{array}{r}14 \\
7 \\
15\end{array}$ & $\begin{array}{l}142 \\
134 \\
244\end{array}$ & $\begin{array}{l}0.007 \pm 0.024 \\
0.004 \pm 0.026 \\
0.029 \pm 0.019\end{array}$ & $\begin{array}{l}0.312 \\
0.136 \\
1.525\end{array}$ \\
\hline$B^{c}$ & $\begin{array}{l}\mathrm{C} \\
\mathrm{C} \times \mathrm{B} \\
\mathrm{B} \times \mathrm{C}\end{array}$ & $\begin{array}{r}8 \\
11 \\
9\end{array}$ & $\begin{array}{l}114 \\
207 \\
153\end{array}$ & $\begin{array}{r}-0.018 \pm 0.035 \\
0.018 \pm 0.028 \\
0.012 \pm 0.022\end{array}$ & $\begin{array}{l}0.501 \\
0.624 \\
0.542\end{array}$ \\
\hline$B^{G}$ & $\begin{array}{l}\mathrm{C} \\
\mathrm{C} \times \mathrm{B} \\
\mathrm{B} \times \mathrm{C}\end{array}$ & $\begin{array}{r}7 \\
17 \\
13\end{array}$ & $\begin{array}{r}88 \\
330 \\
190\end{array}$ & $\begin{array}{l}-0.069 \pm 0.049 \\
-0.006 \pm 0.019 \\
-0.007 \pm 0.019\end{array}$ & $\begin{array}{l}1.418 \\
0.323 \\
0.367\end{array}$ \\
\hline$B^{I}$ & $\begin{array}{c}\stackrel{\mathrm{B}}{\mathrm{C}} \\
\mathrm{C} \times \mathrm{B} \\
\mathrm{B} \times \mathrm{C}\end{array}$ & $\begin{array}{r}15 \\
9 \\
14 \\
15\end{array}$ & $\begin{array}{l}145 \\
109 \\
306 \\
240\end{array}$ & $\begin{array}{r}-0.010 \pm 0.023 \\
0.015 \pm 0.039 \\
-0.006 \pm 0.018 \\
-0.000 \pm 0.020\end{array}$ & $\begin{array}{l}0.426 \\
0.396 \\
0.316 \\
0.004\end{array}$ \\
\hline$B^{M}$ & $\begin{array}{l}\mathrm{B} \\
\mathrm{C} \times \mathrm{B} \\
\mathrm{B} \times \mathrm{C}\end{array}$ & $\begin{array}{r}14 \\
9 \\
16\end{array}$ & $\begin{array}{l}134 \\
223 \\
252\end{array}$ & $\begin{array}{r}-0.013 \pm 0.025 \\
0.031 \pm 0.020 \\
-0.009 \pm 0.017\end{array}$ & $\begin{array}{l}0.536 \\
1.505 \\
0.555\end{array}$ \\
\hline
\end{tabular}

Tables 3. Average effects of the $B$-locus alleles on the rate of egg production during the first three laying months.

\begin{tabular}{|c|c|c|c|c|c|}
\hline Gene & Strain & $\begin{array}{l}\text { No. of sire } \\
\text { families }\end{array}$ & $\begin{array}{l}\text { No. of } \\
\text { hens }\end{array}$ & $\begin{array}{c}\text { Average effects } \\
\text { of genes }(\bar{D} \pm S E \bar{D})\end{array}$ & $t$ \\
\hline$B^{A}$ & 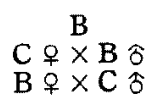 & $\begin{array}{r}7 \\
6 \\
12\end{array}$ & $\begin{array}{r}95 \\
103 \\
211\end{array}$ & $\begin{array}{l}4.79 \pm 1.97 \\
2.01 \pm 2.44 \\
6.03 \pm 2.35\end{array}$ & $\begin{array}{l}2.435 * \\
0.826 \\
2.560 *\end{array}$ \\
\hline$B^{B M}$ & $\begin{array}{l}\mathrm{B} \\
\mathrm{C} \times \mathrm{B} \\
\mathrm{B} \times \mathrm{C}\end{array}$ & $\begin{array}{r}14 \\
7 \\
15\end{array}$ & $\begin{array}{l}144 \\
133 \\
244\end{array}$ & $\begin{array}{l}-1.33 \pm 1.39 \\
-0.31 \pm 2.27 \\
-1.27 \pm 1.91\end{array}$ & $\begin{array}{l}0.956 \\
0.136 \\
0.666\end{array}$ \\
\hline$B^{c}$ & $\begin{array}{l}\mathrm{C} \\
\mathrm{C} \times \mathrm{B} \\
\mathrm{B} \times \mathrm{C}\end{array}$ & $\begin{array}{r}8 \\
11 \\
9\end{array}$ & $\begin{array}{l}118 \\
207 \\
153\end{array}$ & $\begin{array}{r}-0.80 \pm 1.86 \\
0.29 \pm 2.55 \\
-2.24 \pm 2.16\end{array}$ & $\begin{array}{l}0.429 \\
0.115 \\
1.038\end{array}$ \\
\hline$B^{G}$ & $\begin{array}{l}\mathrm{C} \\
\mathrm{C} \times \mathrm{B} \\
\mathrm{B} \times \mathrm{C}\end{array}$ & $\begin{array}{r}7 \\
17 \\
13\end{array}$ & $\begin{array}{r}89 \\
335 \\
190\end{array}$ & $\begin{array}{r}1.54 \pm 2.57 \\
-2.02 \pm 1.67 \\
3.28 \pm 1.85\end{array}$ & $\begin{array}{l}0.598 \\
1.209 \\
1.772\end{array}$ \\
\hline$B^{I}$ & $\begin{array}{l}\stackrel{B}{C} \\
C \times B \\
B \times C\end{array}$ & $\begin{array}{r}15 \\
9 \\
14 \\
15\end{array}$ & $\begin{array}{l}151 \\
113 \\
307 \\
240\end{array}$ & $\begin{array}{r}-1.57 \pm 1.32 \\
0.46 \pm 1.99 \\
1.06 \pm 1.65 \\
-1.96 \pm 1.86\end{array}$ & $\begin{array}{l}1.185 \\
0.233 \\
0.643 \\
1.056\end{array}$ \\
\hline$B^{M}$ & $\begin{array}{c}\mathrm{B} \\
\mathrm{C} \times \mathrm{B} \\
\mathrm{B} \times \mathrm{C}\end{array}$ & $\begin{array}{r}14 \\
9 \\
16\end{array}$ & $\begin{array}{l}140 \\
224 \\
252\end{array}$ & $\begin{array}{r}1.43 \pm 1.39 \\
-0.35 \pm 1.82 \\
-1.82 \pm 1.67\end{array}$ & $\begin{array}{l}1.025 \\
0.192 \\
1.092\end{array}$ \\
\hline
\end{tabular}

* Significant at the $5 \%$ level of probability.

four alleles, $B^{A}, B^{B M}, B^{I}$ and $B^{M}$ are prevalent; and in the $C$ strain, $B^{C}, B^{G}$ and $B^{I}$ occur frequently. 


\section{Blood Groups and Production Characters}

The results of the test for the average of blood group alleles on performance are presented in Tables 1 to 5 . The number of hens for each particular allele varied somewhat depending on the character tested. This is due to the fact that data on a given character were missing for some birds. As shown in Table 1, the difference in sexual maturity was small for each comparison. Only one comparison was significant at the 5 percentlevel. That is, in the $\mathrm{C} \times \mathrm{B}$ crosses, chickens having the $B^{M}$ gene reached sexual maturityabout four days later than those lacking this gene. It is, however, expected that on the average 5 percent of such comparisons would appear to be significant by chance alone in the absence of any gene effects. In the table there are 19 comparisons; therefore, it is questionable whether this difference was due to real gene effects (also see Table 6). For body weight at sexual maturity there were no significant differences (Table 2). In the case of egg production rate, significant effects of blood group genes were detected in two comparisons (Table 3 ). Both in the $B$ and $B \times C$ populations, chickens which carried the $B^{A}$ allele showed significantly higher production rates than those lacking this gene. This effect was also shown in another comparison in the $C \times B$ population, though it was not significant statistically. As shown in Table 4, the same tendency was seen for the comparisons of egg production intensity, in which one comparison was significant. These results suggest that this difference might be caused by a real effect of the allele $B^{A}$. Table 5 presents additional data on the $B^{A}$ gene effect, showing that this allele is associated significantly with low egg weight.

$\chi^{2}$ values were calculated for examining whether comparisons between groups of $B$ blood group alleles were significant as a whole. The results are summarized in Table 6 . In accordance with the findings in Tables 3 and 4, two values, namely the egg production rate of the $\mathrm{C} \times \mathrm{B}$ crosses and the production intensity of the $\mathrm{B}$ strain, were significant at the 5 percent

Table 4. Average effects of the $B$-locus alleles on the intensity of egg production during the first three laying months.

\begin{tabular}{cccccc}
\hline \hline Gene & Strain & $\begin{array}{c}\text { No. of sire } \\
\text { families }\end{array}$ & $\begin{array}{c}\text { No. of } \\
\text { hens }\end{array}$ & $\begin{array}{c}\text { Average effects } \\
\text { of genes }(\bar{D} \pm S E \bar{D})\end{array}$ & $t$ \\
\hline \multirow{3}{*}{$B^{A}$} & $\mathrm{C}$ B $\times$ B & 7 & 95 & $3.60 \pm 1.49$ & $2.407^{*}$ \\
& $\mathrm{~B}+\mathrm{O} \times \mathrm{C}$ & 12 & 103 & $0.42 \pm 1.28$ & 0.325 \\
$B^{B M}$ & $\mathrm{~B}$ & 14 & 144 & $-1.59 \pm 1.04$ & 1.704 \\
& $\mathrm{C} \times \mathrm{B}$ & 7 & 133 & $-0.58 \pm 1.18$ & 0.491 \\
& $\mathrm{~B} \times \mathrm{C}$ & 15 & 244 & $-1.34 \pm 1.03$ & 1.302 \\
$B^{C}$ & $\mathrm{C}$ & 8 & 118 & $0.12 \pm 1.13$ & 0.110 \\
& $\mathrm{C} \times \mathrm{B}$ & 11 & 207 & $0.02 \pm 1.35$ & 0.012 \\
& $\mathrm{~B} \times \mathrm{C}$ & 9 & 153 & $-0.98 \pm 1.16$ & 0.847 \\
$B^{c}$ & $\mathrm{C}$ & 7 & 89 & $1.61 \pm 1.56$ & 1.030 \\
& $\mathrm{C} \times \mathrm{B}$ & 17 & 334 & $-0.52 \pm 0.87$ & 0.597 \\
$B^{I}$ & $\mathrm{~B} \times \mathrm{C}$ & 13 & 190 & $1.67 \pm 0.99$ & 1.680 \\
& $\mathrm{~B}$ & 15 & 151 & $-0.88 \pm 0.84$ & 1.051 \\
& $\mathrm{C}$ & 9 & 113 & $1.68 \pm 1.20$ & 1.396 \\
& $\mathrm{C} \times \mathrm{B}$ & 14 & 307 & $-0.01 \pm 0.86$ & 0.010 \\
$B^{M}$ & $\mathrm{~B} \times \mathrm{C}$ & 15 & 240 & $-0.57 \pm 1.00$ & 0.568 \\
& $\mathrm{~B}$ & 14 & 140 & $0.87 \pm 1.09$ & 0.798 \\
& $\mathrm{C} \times \mathrm{B}$ & 9 & 224 & $0.69 \pm 0.94$ & 0.740 \\
& $\mathrm{~B} \times \mathrm{C}$ & 16 & 252 & $-0.53 \pm 0.91$ & 0.581 \\
\hline
\end{tabular}

* Significant at the $5 \%$ level of probability. 


\section{OKada - Hasegawa - Semidera - Shimizu - Hachinohe}

Table 5. Average effects of the $B$-locus alleles on egg weight at ten months of age.

\begin{tabular}{cccccc}
\hline Gene & Strain & $\begin{array}{c}\text { No. of sire } \\
\text { families }\end{array}$ & $\begin{array}{c}\text { No. of } \\
\text { hens }\end{array}$ & $\begin{array}{c}\text { Average effect } \\
\text { of genes }(\bar{D} \pm S E \bar{D})\end{array}$ & $t$ \\
\hline$B^{A}$ & $\mathrm{~B}$ & 7 & 94 & $-1.03 \pm 0.50$ & $2.062^{*}$ \\
$B^{B M}$ & $\mathrm{~B}$ & 14 & 144 & $0.86 \pm 0.40$ & 1.781 \\
$B^{C}$ & $\mathrm{C}$ & 8 & 118 & $0.75 \pm 0.71$ & 1.057 \\
$B^{G}$ & $\mathrm{C}$ & 7 & 89 & $1.30 \pm 0.78$ & 1.658 \\
$B^{I}$ & $\mathrm{~B}$ & 15 & 150 & $-0.41 \pm 0.45$ & 0.909 \\
& $\mathrm{C}$ & 9 & 112 & $-0.84 \pm 0.64$ & 1.318 \\
$B^{M}$ & $\mathrm{~B}$ & 14 & 138 & $-0.41 \pm 0.50$ & 0.819
\end{tabular}

* Significant at the $5 \%$ level of probability.

Table 6. The joint effects of the $B$-locus alleles as estimated by $\chi^{2}$ values.

\begin{tabular}{|c|c|c|c|c|c|c|}
\hline Strain & $\begin{array}{l}\text { Degree of } \\
\text { freedom }\end{array}$ & $\begin{array}{l}\text { Sexual } \\
\text { maturity }\end{array}$ & $\begin{array}{l}\text { Body } \\
\text { weight }\end{array}$ & $\begin{array}{l}\text { Egg produc- } \\
\text { tion rate }\end{array}$ & $\begin{array}{l}\text { Egg produc- } \\
\text { tion intensity }\end{array}$ & $\underset{\text { weight }}{\text { Egg }}$ \\
\hline $\mathrm{B}$ & 4 & 0.245 & 1.863 & 9.207 & $9.547^{*}$ & 6.655 \\
\hline $\mathrm{C}$ & 3 & 3.995 & 2.377 & 0.602 & 2.871 & 6.244 \\
\hline $\mathrm{C}+9 \times \mathrm{B} \&$ & 6 & 8.130 & 6.587 & 2.648 & 1.247 & - \\
\hline $\mathrm{B} \% \times \mathrm{C}$ \% & 6 & 4.628 & 3.711 & $13.543^{*}$ & 8.909 & - \\
\hline
\end{tabular}

* Significant at the $5 \%$ level of probability.

Table 7. The variance controlled by blood group genes at the $B$ locus.

\begin{tabular}{|c|c|c|c|c|}
\hline Character & Strain & $\begin{array}{l}\text { Variance } \\
\text { within sire } \\
\text { families }\end{array}$ & $\begin{array}{l}\text { Estimate of variance } \\
\text { due to blood group } \\
\text { differences }\end{array}$ & $\begin{array}{l}\text { Proportion within } \\
\text { sire families due to } \\
\text { blood groups }(\%)\end{array}$ \\
\hline Sexual maturity & $\begin{array}{c}\stackrel{\mathrm{B}}{\mathrm{C}} \\
\mathrm{C} \stackrel{\circ}{\mathrm{B}} \times \mathrm{B} \delta \\
\mathrm{B} \times \mathrm{C} \delta\end{array}$ & $\begin{array}{l}375.21 \\
280.75 \\
209.51 \\
212.24\end{array}$ & $\begin{array}{r}-9.65 \\
1.74 \\
1.41 \\
-1.24\end{array}$ & $\begin{array}{r}-2.6 \\
0.6 \\
0.7 \\
-0.6\end{array}$ \\
\hline Body weight & $\begin{array}{c}\mathrm{B} \\
\mathrm{C} \\
\mathrm{C} \times \mathrm{B} \\
\mathrm{B} \times \mathrm{C}\end{array}$ & $\begin{array}{l}0.01669 \\
0.02805 \\
0.01819 \\
0.01564\end{array}$ & $\begin{array}{r}-0.00025 \\
-0.00011 \\
0.00003 \\
-0.00015\end{array}$ & $\begin{array}{r}-1.4 \\
-0.3 \\
0.2 \\
-1.0\end{array}$ \\
\hline $\begin{array}{l}\text { Egg production } \\
\text { rate }\end{array}$ & $\begin{array}{c}\mathrm{B} \\
\mathrm{C} \\
\mathrm{C} \times \mathrm{B} \\
\mathrm{B} \times \mathrm{C}\end{array}$ & $\begin{array}{r}58.43 \\
76.78 \\
146.85 \\
145.34\end{array}$ & $\begin{array}{r}2.03 \\
-1.13 \\
-1.54 \\
4.65\end{array}$ & $\begin{array}{r}3.4 \\
-1.4 \\
-1.1 \\
3.2\end{array}$ \\
\hline $\begin{array}{l}\text { Egg production } \\
\text { intensity }\end{array}$ & $\begin{array}{l}\mathrm{B} \\
\mathrm{C} \\
\mathrm{C} \times \mathrm{B} \\
\mathrm{B} \times \mathrm{C}\end{array}$ & $\begin{array}{l}33.43 \\
29.11 \\
40.03 \\
42.16\end{array}$ & $\begin{array}{r}1.24 \\
-0.02 \\
-0.60 \\
0.52\end{array}$ & $\begin{array}{r}3.6 \\
-0.1 \\
-1.4 \\
1.2\end{array}$ \\
\hline Egg weight & $\begin{array}{l}\mathrm{B} \\
\mathrm{C}\end{array}$ & $\begin{array}{l}7.227 \\
7.233\end{array}$ & $\begin{array}{l}0.131 \\
0.144\end{array}$ & $\begin{array}{l}1.7 \\
2.0\end{array}$ \\
\hline
\end{tabular}

level; and one, the production rate of the B strain, approached significance. A detailed check of the data showed that the major source of this significance was the effect of the $B^{A}$ allele. 


\section{Blood Groups and Production Characters}

For sexual maturity and egg weight there were no significant effects in contrast to the case in certain direct comparisons (Tables 1 and 5).

Estimates of the total variance within sire families for the five production traits, and the amount of variance due to the blood group alleles, are given in Table 7 . The estimates mostly ranged from -2.0 to 2.0 percent. The figures for the characters which showed significant or nearly significant $\chi^{2}$ values were 3.2 to 3.6 , but their standard errors, not shown in the table, were as high as 2.8 to 3.7 .

The analysis of variance between the segregation classes of heterozygous sires was done only for the strain-cross progeny. Both in the $\mathrm{B}$ and $\mathrm{C}$ strains, it was impossible to divide into segregation classes, because the sire and the dam mated frequently had the same genotype. The results are shown in Table 8 . No significant differences were found.

Table 8. Differences between segregation classes of the progeny from heterozygous sires.

\begin{tabular}{|c|c|c|c|c|c|}
\hline \multirow{3}{*}{ Character } & \multirow{3}{*}{ Strain } & \multicolumn{4}{|c|}{ Analyses of variance } \\
\hline & & \multicolumn{2}{|c|}{$\begin{array}{l}\text { Between segregation } \\
\text { classes within sires }\end{array}$} & \multicolumn{2}{|c|}{$\begin{array}{c}\text { Within segregation } \\
\text { classes }\end{array}$} \\
\hline & & d.f. & Mean square & d.f. & Mean square \\
\hline Sexual maturity & $\begin{array}{l}\mathrm{C} \text { 우 } \times \mathrm{B} \text { 合 } \\
\mathrm{B} \text { 우 } \times \mathrm{C} \text { 令 }\end{array}$ & $\begin{array}{l}15 \\
13\end{array}$ & $\begin{array}{l}236.60 \\
217.75\end{array}$ & $\begin{array}{l}256 \\
151\end{array}$ & $\begin{array}{l}196.91 \\
219.02\end{array}$ \\
\hline Body weight & $\begin{array}{l}\mathrm{C} \times \mathrm{B} \\
\mathrm{B} \times \mathrm{C}\end{array}$ & $\begin{array}{l}15 \\
13\end{array}$ & $\begin{array}{l}0.0199 \\
0.0205\end{array}$ & $\begin{array}{l}257 \\
152\end{array}$ & $\begin{array}{l}0.0175 \\
0.0139\end{array}$ \\
\hline $\begin{array}{l}\text { Egg production } \\
\text { rate }\end{array}$ & $\begin{array}{l}\mathrm{C} \times \mathrm{B} \\
\mathrm{B} \times \mathrm{C}\end{array}$ & $\begin{array}{l}15 \\
13\end{array}$ & $\begin{array}{r}66.23 \\
112.78\end{array}$ & $\begin{array}{l}256 \\
150\end{array}$ & $\begin{array}{l}103.53 \\
102.06\end{array}$ \\
\hline $\begin{array}{l}\text { Egg production } \\
\text { intensity }\end{array}$ & $\begin{array}{l}\mathrm{C} \times \mathrm{B} \\
\mathrm{B} \times \mathrm{C}\end{array}$ & $\begin{array}{l}15 \\
13\end{array}$ & $\begin{array}{l}35.33 \\
32.25\end{array}$ & $\begin{array}{l}256 \\
150\end{array}$ & $\begin{array}{l}32.94 \\
45.21\end{array}$ \\
\hline
\end{tabular}

Thus, there is no evidence of linkage between the $B$ locus and genes affecting the performance criteria under study.

\section{Discussion}

Quantitative characters such as body weight or egg production are the end expression of multitudinous physiological processes, and are greatly influenced by environmental conditions. Therefore, the magnitude of the differences associated with various alleles at a particular locus would usually be expected to be small. Nevertheless, such differences could be important at the population level.

There are several reports on association between blood group genes and production characters in various species: for example, in cattle, MitscherLich et al. ${ }^{(5)}$; in sheep, StansFIELD et $a l .^{25)}$; and in swine, BALTZER ${ }^{6}$. Especially in dairy cattle there have been reported encouraging results on this problem. A consistently significant association between the allele $B B O_{1} Y_{2} D^{\prime}$ and butterfat percentage in milk has been found in various breeds of different countries. ${ }^{8,17,20\}}$

In chickens, however, most studies have been done on heterotic effects of blood group. alleles. $\left.{ }^{7}, 12,18\right)$ Only a few works have been published on effects of a particular allele. ${ }^{2,8}$ ) In 


\section{OKada $\cdot$ HasegaWa $\cdot$ SeKidera $\cdot$ Shimizu $\cdot$ Hachinohe}

the present studies, about 6 percent of the $\bar{D}$ values (5 of 82 comparisons) were significant statistically (Tables 1 to 5 ). This is near the proportion ( 5 percent) that would be expected by chance alone in the absence of any gene effects. However, all the significant associations, except for one case involving the allele $B^{M}$, depended on the allele $B^{A}$, which was associated with increased egg production and decreased egg weight. This result agrees with the negative genetic correlation between winter egg production and March egg weight reported by Abplanalp ${ }^{11}$. In addition to that, the joint effects of the $B$-locus alleles, estimated by the $\chi^{2}$ test, were also significantly associated with egg production of the $B$ strain and of the $B \times C$ populations, respectively (Table 6). The allele $B^{A}$ was the major source of the effect.

It is difficult to determine from the present data whether this effect of $B^{A}$ on egg production characteristics is due to linkage or to true pleiotropic effects of the $B$ locus. Even if linkage were assumed, recombination would randomize the association during the lapse of generations. The populations studied here have been closed for more than ten generations, and furthermore the test for linkage using heterozygous sires gave negative results (Table 8). This association, therefore, is most likely pleiotropic, including the possibility of super-gene system consisting of groups tightly linked with the $B$ locus..11,21,22) Furthermore, the general existence of multiple allelism ${ }^{7}$ and superior fitness of heterozygotes ${ }^{18}$ at the $B$ locus support the idea that this association is due to pleiotropic effects of the $B$-locus alleles. If this is a a real pleiotropic effect, there must be consistent trend, as in the case of the allele $B B_{1} Y_{2} D^{\prime}$ in cattle, although the effect will vary to some extent according to the genetic background of the population. In chickens, ALLEN and his coworker, ${ }^{2,3)}$ found such a tendency in comparisons of the allele $B^{13}$ versus $B^{14}$, and of $B^{8}$ versus $B^{9}$, respectively, in several genetically different populations. The present data also show this tendency; that is, the allele $B^{A}$ was associated with increased egg production in all three populations.

Thus, evidence presented here leads to the conclusion that there are definite associations of the $B$-locus alleles with performance. From a practical point of view, however, this does not insure the possibility of applying blood grouping to practical breeding. As shown in Table 7 , the fraction of variance controlled by blood group genes was small. For example, the highest value was 3.6 percent for the intensity of egg production in the B strain, and its standard error amounted to 3.7 percent. These figures represent the proportion of the variance within families, but an important figure is the proportion of the total genetic variance related to the bloodgroup alleles. The estimate of heritability for winter egg production is in the neigh- bourhood of 0.3 according to YAMADA. ${ }^{26}$ ) If we adopt this value tentatively for the egg production intensity, it is estimated that about 10 percent of the genetic variation in the $B$ strain is due to variation in alleles at the $B$ locus. However, it would not be safe to take this figure at face value because of the high value of its standard error. Moreover, in chickens there are technical difficulties in the development of useful blood typing reagents for genetically unrelated populations. These facts lead the authors to a pessimistic conclusion regarding practical applications of blood groups to selection.

\section{Summary}

Studies have been conducted on the associations between the multiallelic $B$ blood group locus and production characters. Data were obtained from 935 birds of two closed S.C. White Leghorn strains and their cross-progeny. The production characters studied were 


\section{Blood Groups and Production Characters}

sexual maturity, body weight, the rate and intensity of egg production and egg weight.

The comparisons dealt with were made by two methods. One was to examine the average effect of particular alleles on performance, and the other was to detect differences between the segregation classes of progeny from heterozygous sires. All statistical tests were carried out within groups of paternal half sibs.

The results of direct comparisons of gene effects showed that 5 of 82 comparisons were significant statistically. These associations were mostly found between the allele $B^{A}$ and egg production. The proportion of variance controlled by the $B$-locus alleles ranged mostly from -2.0 to 2.0 percent of the total variance within sire families, but that for characters showing significant differences was 3.2 to 3.6 percent.

In the analysis of progeny from heterozygous sires, no differences were found for any character between the segregation classes.

\section{Acknowledgment}

The authors wish to express their appreciation to Dr. W.J. MeLiEn, University of Massachusetts, Amherst, Mass., U.S.A., for reading the paper in manuscript and offering his valuable suggestions.

\section{References}

1) Abplanaly, H. (1957) Poult. Sci., 36: 226-228.

2) Allen, C.P. (1962) Ann. New York Acad. Sci., $97: 184-193$.

3) Allen, C.P. and D.G. Gilmour (1962) Genetics, $47: 1711-1718$.

4) Ashton, G.C., G.R. Fallon and D.N. Sutherdand (1964) J. Agric. Sci., $62: 27-34$.

5) BALtzer, J. (1964) Züchtungskunde, $36: 317-326$.

6) Briles, W.E. and C.P. Allen (1961) Genetics, $46: 1273-1293$.

7) Briles, W.E., C.P. Allen and T.W. Millen (1957) Genetics, $42: 631-648$.

8) Briles, W.E., L.W. Johnson and M.T. Garber (1953) Poult. Sci., 32: 890.

9) Conneally, P.M. and W.H. Stone (1965) Nature, $206: 115$.

10) CRAW Ford, R.D. and E.S. MerritT (1963) Canad. J. Genet. Cytol., $5: 89-95$.

11) FoRd, E.B. (1955) Cold Spr. Harb. Symp. Quant. Biol., $20: 230-238$.

12) Gilmour, D.G. (1959) Genetics, $44: 14-33$.

13) Kristjansson, F.K. (1964) J. Reprod. Fertil., $8: 311-317$.

14) Matsumoto, K. and I. OkadA (1961) Jap. J. Genet., $36: 257-267$.

15) Mitscherlich, E., A. Tolle und E. Walter (1959) Z. Tierz. Züchtbiol., 72: 289-301.

16) Morton, J.R., D.G. Gilmour, E.M. McDermid and A.L. Ogden (1965) Genetics, 51 : 97-107.

17) Nemann-S $\phi_{\text {Rensen, }}$ A. and A. Robertson (1961) Acta Agric. Scand., $11: 163-196$.

18) OKadA, I. and K. Matsumoto (1962) Jap. J. Genet., $37: 267-275$.

19) Okada, I., S. Takagi and K. Matsumoto (1962) Jap. J. Genet., 37 : 102-109.

20) Rendel, J. (1959) Rept. VI Int. Blood Group Congr. Munich, pp. 8-23.

21) Sheppard, P.M. (1953) Amer. Nat., $87: 283-294$.

22) Sheppard, P.M. (1955) Cold. Spr. Harb. Symp. Quant. Biol., $20: 271-275$.

23) ShuLtz, F.T. and W.E. Briles (1953) Genetics, $38: 34-50$. 


\title{
OKada - Hasegawa $\cdot$ Sekidera $\cdot$ Shimizu $\cdot$ Hachinohe
}

24) Smyth, J.R., JR. and T.W. Fox (1963) Poult. Sci., 42 : 1441-1445.

25) Stansfield, W.D., G.E. Bradford, C. Stormont and R.L. Blackpell (1964) Genetics, $50: 1357-1367$.

26) YamadA, Y. (1958) Jap. J. Genet., $33: 13-22$.

\section{鶏の $B$ 座位遺伝子と産卵諸形質々の関連性}

\author{
岡田 育穂 - 長谷川 保*,1) ・ 関寺 章八*,3) ・ \\ 清 水弘・八戸 芳夫 \\ (北海道大学農学部・*農林省大宮種畜牧場)
}

稳の血液型安支配する $B$ 座位の対立遗伝子女産卵諸形 質との関連性が, 935 羽の単冠白色レダホン種について 研究された。データは農林省大宮種畜牧場で铝荃されて いた B，C両系統とその交雑群加ら得られた. 対象形質 としては, 初産日令, 初産体重, 初産より90日間の産 卵率および産卵強度, 10 力月令における卵重の 5 形質が 選ばれた。調査された遺伝子は $B^{A}, B^{B M}, B^{C}, B^{G}, B^{I}$ および $B^{M}$ のつである。

遗伝子効果の比較は二つの方法で行なるれた．その一 つは特定遺伝子の産卵諸形質へ及ぼす平均効果を調べる ととであり，もう一つはへテロの父鵎からの後代につい

1) 現所属：林省岡踦稳畜牧場。

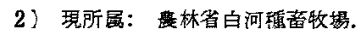

て，その遺伝子の分離の組間の差を比較することであ る.これらの比較性，すべて父方の半きようだい内で行 なわれだ。

遺伝子の平均効果化つての結果は，82の比教のうち

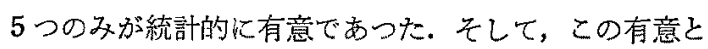
なつだものは，BMよる一つ壳除いて，すべて $B^{A}$ 遗伝 子によるもので, 主として産卵率または産卵強度と関連 していた。また，B座位の対立遗伝子に上る分散の父親

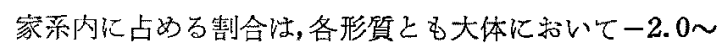
$2.0 \%$ の籍囲にあつた．しかし，有意または有意に近い 值を示した形質では $3.2 \sim 3.6 \%$ の值を示した.

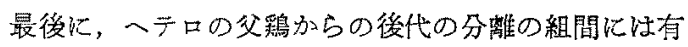
意な差は見出されなかつた。 